\title{
Recurrent acute pancreatitis in a Wilson disease patient: an unusual association
}

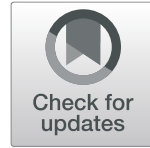

\author{
Sanjay Kumar ${ }^{*}$ D, Sridhar Sundaram, Harish Darak, Suprabhat Giri and Shobna Bhatia
}

\begin{abstract}
Background: Wilson's disease is a multisystem disorder with predominant clinical symptoms depending on the site of copper deposition in the body. Hepatic presentation is usually seen in the younger age group. And pancreatitis is rarely associated with Wilson's disease. To the best of our knowledge, recurrent acute pancreatitis as a presenting manifestation in a WD patient has not been mentioned before in the literature.

Case presentation: We report a 17-year-old boy who presented with recurrent acute pancreatitis and subsequently developed deranged liver enzymes and ascites. Work up for the cause of recurrent acute pancreatitis was normal. Low ceruloplasmin $(0.07 \mathrm{mg} / \mathrm{dL})$, high $24-\mathrm{h}$ urinary copper excretion $(576 \mu \mathrm{g} /$ day), and dry copper content in the liver $(270 \mu \mathrm{g} / \mathrm{g})$ clinched the diagnosis of Wilson's disease. The patient was started on a low-copper diet and Dpenicillamine therapy resulting in an improvement in symptoms and no further recurrence of pancreatitis.
\end{abstract}

Conclusion: The possibility of Wilson's disease should be considered in young patients with recurrent acute pancreatitis, who have a protracted and obscure disease course.

Keywords: Wilson's disease, Recurrent acute pancreatitis, Copper metabolism, Serum ceruloplasmin, 24-h urinary copper, D-Penicillamine

\section{Background}

Wilson disease (WD) is an autosomal recessive disorder of copper transport causing copper accumulation in the liver and brain primarily $[1,2]$. However, copper also accumulates in organs such as the kidney, bone, blood, cornea, and endocrine glands such as the pancreas [3]. WD-associated pancreatitis is described rarely in literature [4-6]. It was attributed to either copper deposition in the pancreas or biliary stones $[7,8]$. Acute pancreatitis was index presentation in the earlier case reports. And the presence of gallstones, cholangitis, or anemia with protracted jaundice and positive family history led to suspicion of WD in these cases. In the present report, the index case had recurrent acute pancreatitis (RAP) episodes before developing features of chronic liver disease which lead us to consider the possibility of WD [8].

\footnotetext{
* Correspondence: drsanjaykumar.am@gmail.com

Department of Gastroenterology, Seth GS Medical College and King Edward Memorial Hospital, Room No 1243, New Building, Parel, Mumbai, Maharashtra 400012, India
}

\section{Case presentation}

A 17-year-old boy born of non-consanguineous marriage was admitted 3 years back with epigastric pain radiating to the back associated with vomiting for 1 day. ing evaluated for the cause of RAP, serum calcium, trinative me started taking complementary and altergulu, and one unlabelled) and remained asymptomatic for 1 year. However, he started complaining of right hypochondriac pain with vomiting. Laboratory evaluation showed hemoglobin $12 \mathrm{~g} / \mathrm{dL}$, total leucocyte count 7400 per cu.mm, platelet count 1.0 lacs per cubic 
$\mathrm{mm}$, total bilirubin $0.8 \mathrm{mg} / \mathrm{dL}$, SGPT $300 \mathrm{U} / \mathrm{L}$ (normal $<40 \mathrm{U} / \mathrm{L}$ ), and SGOT $305 \mathrm{U} / \mathrm{L}$ (normal < $40 \mathrm{U} / \mathrm{L}$ ) with alkaline phosphatase $217 \mathrm{IU} / \mathrm{L}$ (normal $<117 \mathrm{IU} / \mathrm{L}$ ) and serum lipase $1650 \mathrm{U} / \mathrm{L}$ (normal < $160 \mathrm{U} / \mathrm{L}$ ). USG abdomen suggested a bulky pancreas with normal liver echo texture. The possibility of drug-induced liver injury with pancreatitis was considered. Liver enzymes were continuously monitored and showed a declining trend. $\mathrm{He}$ gradually developed jaundice and abdominal distension with bilateral pedal edema and referred to our center.

On admission, he was icteric with pedal edema, ascites, and palpable splenomegaly. The rest of the examination was normal. Laboratory values on admission were hemoglobin $8.3 \mathrm{~g} / \mathrm{dL}$, total leucocyte count 11,400, and platelet count 1.4 lacs cu.mm. Liver function test values were total bilirubin $5.2 \mathrm{mg} / \mathrm{dL}$ (direct bilirubin $3.6 \mathrm{mg} / \mathrm{dL}$ ), SGOT $167 \mathrm{U} / \mathrm{L}$, SGPT $42 \mathrm{U} / \mathrm{L}$,

Table 1 Timeline of presentation of the index case

\begin{tabular}{|c|c|c|c|c|c|c|c|c|}
\hline & $1^{\text {st episode }}$ & \multicolumn{2}{|c|}{ Pancreatitis } & \multicolumn{5}{|c|}{ CAM intake for 1year on CAM stoppage for 6 months d-Penicillamine started } \\
\hline & $\begin{array}{l}36 \text { months } \\
\text { prior }\end{array}$ & $\begin{array}{l}\text { 30months } \\
\text { prior }\end{array}$ & $\begin{array}{l}24 \\
\text { months } \\
\text { prior }\end{array}$ & $\begin{array}{l}12 \\
\text { months } \\
\text { prior }\end{array}$ & $\begin{array}{l}6 \text { months } \\
\text { prior }\end{array}$ & $\begin{array}{l}\text { Day of } \\
\text { admission }\end{array}$ & $\begin{array}{l}3 \text { months } \\
\text { after } d- \\
\text { penicillamine }\end{array}$ & $\begin{array}{l}6 \text { months } \\
\text { after } d- \\
\text { penicillamine }\end{array}$ \\
\hline Hemogram (g/dL) & 12 & 10.2 & 11.2 & 12 & 11.8 & 8.3 & 9.3 & 10.3 \\
\hline $\begin{array}{l}\text { Total Leucocyte } \\
\text { count (per cu.mm) }\end{array}$ & 13,300 & 13000 & 13400 & 7400 & 6230 & 11,400 & 7,900 & 6,900 \\
\hline $\begin{array}{l}\text { Platelet count (per } \\
\text { cu.mm) }\end{array}$ & $2,60,000$ & $3,44,000$ & $3,00,000$ & $1,00,000$ & $1,69,000$ & $1,40,000$ & $1,38,000$ & $1,29,000$ \\
\hline $\begin{array}{l}\text { Total bilirubin / } \\
\text { Direct bilirubin } \\
(\mathrm{mg} / \mathrm{dl})\end{array}$ & $1.0 / 0.3$ & $0.3 / 0.1$ & $0.8 / 0.1$ & $\begin{array}{l}\text { Non- } \\
\text { icteric }\end{array}$ & $1.4 / 0.9$ & $5.2 / 3.6$ & $1.8 / 0.9$ & 1.00 .4 \\
\hline SGOT/SGPT & $34 / 35$ & $39 / 54$ & $30 / 44$ & $305 / 300$ & $205 / 52$ & $167 / 42$ & $120 / 40$ & $62 / 35$ \\
\hline $\begin{array}{l}\text { Alkaline } \\
\text { Phosphatase (IU/L) }\end{array}$ & 212 & 135 & 210 & 217 & 184 & 236 & 184 & 121 \\
\hline S. Lipase (IU/L) & 635 & 965 & 765 & 1650 & & & & \\
\hline $\begin{array}{l}\text { Serum calcium } \\
(\mathrm{mg} / \mathrm{dL})\end{array}$ & & & 9.10 & & & & & \\
\hline $\begin{array}{l}\text { Serum } \\
\text { triglyceride(mg/dL) }\end{array}$ & & & 203 & & & & & \\
\hline $\begin{array}{l}\text { Serum } \\
\text { ceruloplasmin } \\
(\mathrm{mg} / \mathrm{dL}) \\
\end{array}$ & & & & & & 0.07 & & \\
\hline $\begin{array}{l}24 \text { hour Urinary } \\
\text { copper (mcg/day) }\end{array}$ & & & & & & 576 & 500 & $300 \mathrm{mcg} /$ day \\
\hline $\begin{array}{l}\text { Copper content } \\
\text { (Liver biopsy } \\
\text { mcg/gm) }\end{array}$ & & & & & & 270 & & \\
\hline
\end{tabular}


total protein $6.9 \mathrm{~g} / \mathrm{dL}$, and serum albumin $2.6 \mathrm{~g} / \mathrm{dL}$ with prothrombin time $27 \mathrm{~s}$ (control, 13s). The timeline of laboratory investigations and the disease course is mentioned in Table 1. Ultrasonography of the abdomen showed an enlarged liver with altered echo texture, portal vein $13.5 \mathrm{~mm}$ in diameter, splenomegaly $(13 \mathrm{~cm})$, and ascites. Ascitic fluid was low protein $(1.5 \mathrm{~g} / \mathrm{dL})$ and paucicellular. SAAG was 0.7 and ascitic fluid amylase was $40 \mathrm{IU} / \mathrm{L}$. Upper gastrointestinal endoscopy examination was normal. He was evaluated for etiology of chronic liver disease. Tests for hepatitis B and C were negative. Antinuclear antibody, anti-smooth muscle antibody, and anti-liver-kidney microsomal antibody were also negative. Total IgG was $15 \mathrm{~g} / \mathrm{L}(\mathrm{N}<16 \mathrm{~g} / \mathrm{L})$. Urinary copper was $576 \mu \mathrm{g} / 24 \mathrm{~h}$ (normal 15-50 $\mu \mathrm{g} /$ day), serum copper $82.26 \mu \mathrm{g} / \mathrm{dL}(85-15 \mu \mathrm{g} / \mathrm{dL})$, and serum ceruloplasmin $0.07 \mathrm{mg} \%$ (normal > $0.20 \mathrm{mg} \%$ ). KeyserFleischer ring was negative. Liver biopsy showed liver parenchyma with nodular architecture separated by fibrous strands with bile ductular proliferation and orcein positivity in parasepatal hepatocytes in few nodules suggestive of Wilson's disease (Fig. 1). The copper content in the liver biopsy specimen was 270 $\mu \mathrm{g} / \mathrm{g}$ of the dry liver (normal value up to $45 \mu \mathrm{g} / \mathrm{g}$ ). Modified Leipzig score was 5.

He was started on a low-fat, low-copper diet and D-penicillamine therapy with zinc. He was started on $250 \mathrm{mg}$ of D-penicillamine and increased subsequently to $500 \mathrm{mg}$ twice a day. He was followed monthly for the first 3 months and then every 3 months for 1 year with a complete blood count, liver function test, renal function test, urinalysis, and 24-h urinary copper. His symptoms subsided with no recurrence of pain. Liver enzymes showed improvement in total bilirubin $1.8 \mathrm{mg} / \mathrm{dL}$, direct bilirubin $0.9 \mathrm{mg} / \mathrm{dL}$, SGOT

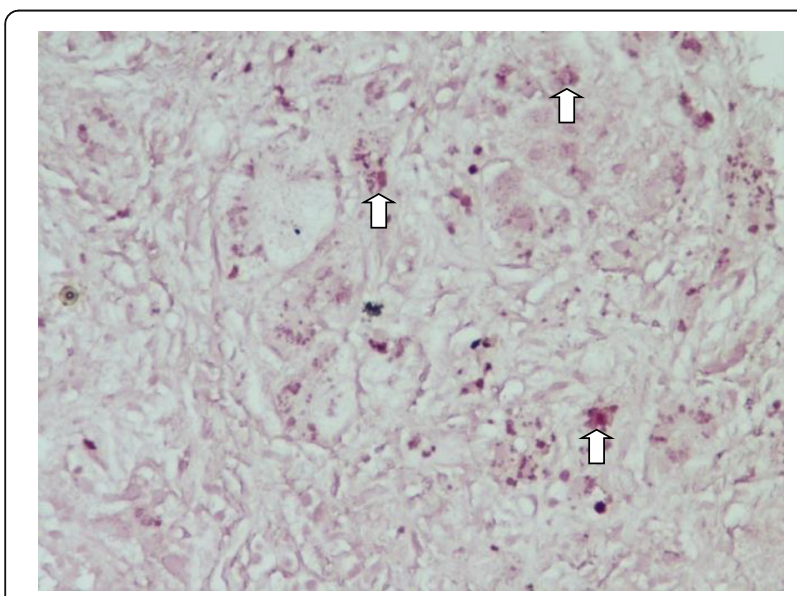

Fig. 1 Liver biopsy showing orcein deposition in granular cytoplasmic inclusion (blank arrow) in hepatocytes $(665 \times 499$ px)
$120 \mathrm{U} / \mathrm{L}, \mathrm{SGPT} 40 \mathrm{U} / \mathrm{L}$, and 24-h urinary copper of $500 \mathrm{mcg}$ per day after 3 months of chelation therapy. No adverse effects were noted during D-penicillamine chelation therapy.

\section{Discussion}

Wilson disease is due to absent or reduced function of ATP7B protein leading to decreased synthesis of ceruloplasmin and increased content in the cellular organelle, causing impaired excretion of copper [4]. Over $200 \mathrm{mu}$ tations of ATP7B genes are possible. Copper is released into the circulation if the capacity of the liver to store copper is exhausted and taken up by virtually all organs [5]. Symptoms depend on the site of deposition of copper in the body.

Scheinberg and Sternlieb first described that 1 out of 5 WD patients have an excess copper concentration in the pancreas [3]. Along with this, 2 other studies have described abnormal pancreatic secretion in patients with WD $[6,9]$. Excess deposition of copper damages each cellular organelle-plasma membrane, cytosolic protein, and other organelles. The accumulated copper disrupts the cell membrane, increases membrane permeability, and causes lysosomal membrane breakages. Such effects may be responsible for the release of proteolytic enzymes leading to autodigestion and inflammation in the pancreas. Such episodes may be transient and self limited [7].

Weizman proposed pancreatic injury because of portal hypertension causing impaired venous drainage of the pancreas or direct cytotoxic effect [8]. Pigmented gallstone due to Coombs-negative hemolysis may also occur, causing pancreatitis, cholangitis, and jaundice [10]. Previously reported cases described index episode of pancreatitis at presentation simultaneously associated with the gallstones, cholangitis, or anemia with protracted jaundice or positive family of WD [8]..

Initial diagnostic tests for recurrent acute pancreatitis were negative. On evaluation of etiology of liver disease, it was found to have decreased serum ceruloplasmin, elevated (> 2 times) urinary copper excretion, and increased (> 5 times) hepatic copper content with a total score of 5 confirming the diagnosis of WD [4]. Following the treatment with Dpenicillamine and a low-copper diet, there was no recurrence of abdominal pain. Though molecular study related to pancreatitis genes, the unknown copper content of complementary herb, and no direct evidence of copper deposition in the pancreatic tissue were lacking in the present study. Even then, the temporal sequence of symptoms initially and improvement with D-penicillamine therapy and low-copper diet may suggest a causal association. 


\section{Conclusion}

The possibility of Wilson's disease should be considered in young patients with recurrent acute pancreatitis, who have a protracted and obscure disease course.

\section{Abbreviations}

WD: Wilson disease; RAP: Recurrent acute pancreatitis; CECT: Contrastenhanced computed tomography; SGOT: Serum glutamate oxaloacetate transferase; SGPT: Serum glutamate pyruvate transferase;

USG: Ultrasonography of the abdomen

\section{Acknowledgements}

I would like to express my sincere thanks to Dr. Nitin Ramani and Dr.Dhiraj Aggarwal for managing and maintaining patient details.

\section{Authors' contributions}

Dr. HD and Dr. SG helped in analyzing the data and writing the manuscript while Dr. SS and Dr. SB edited the document. All authors have read and approved the final manuscript

\section{Funding}

None

\section{Availability of data and materials}

All data generated or analyzed during the study are included in this published article.

\section{Declarations}

Ethics approval and consent to participate

Not applicable

\section{Consent for publication}

Yes; written consent for publication was taken from the parents of the study.

\section{Competing interests}

The authors declare that they have no competiing interest.

Received: 29 April 2021 Accepted: 27 July 2021

Published online: 18 August 2021

\section{References}

1. Ferenci P (2004) Review article: diagnosis and current therapy of Wilson's disease. Aliment PharmacolTher 19:157-165

2. Roberts EA, Schilsky ML (2008) Diagnosis and treatment of Wilson disease: an update. Hepatology 47:2089-2111

3. Scheinberg $I H$, Sternlieb I (1984) Wilson's disease. In: Smith LH (ed) Major problems in internal medicine, vol 1981. WB. Saunders, Philadelphia, pp $111-113$

4. Nagral A, Sarma MS, Matthai J et al (2019) Wilson's disease: clinical practice guidelines of the Indian National Association for Study of the Liver, the Indian Society of Pediatric Gastroenterology, Hepatology and Nutrition, and the Movement Disorders Society of India. J Clin Exp Hepatol 9(1):74-98

5. Kitzberger R, Madl C, Ferenci P (2005) Wilson disease. Metab Brain Dis Vol20, No 4, December 2005:p 295-302.

6. Osswald P, Niessen KH (1976) Insufficiency of the exocrine pancreas in Wilson's disease. Klin Wochenschr 54(17):839-843

7. Weizman Z, Picard E, Barki Y, Moses S (1988) Wilson's disease associated with pancreatitis. J PediatrGastroenterolNutr 7:931-933

8. Nussinson E, Shahbari A, Shibli F et al (2013) Diagnostic challenges of Wilson's disease presenting as acute pancreatitis, cholangitis, and jaundice. World J Hepatol 5(11):649-653

9. McCullough AJ, Fleming CR, Thistle JL et al (1983) Diagnosis of Wilson's disease presenting as fulminant hepatic failure. Gastroenterology 84(1):161

10. Rahul Y, Tarkeshwari, Shanmuganathan S. A case of Wilson's disease presenting as acute pancreatitis. Journal of clinical and experimental Hepatology, July 2018, S123-124.

\section{Publisher's Note}

Springer Nature remains neutral with regard to jurisdictional claims in published maps and institutional affiliations.

\section{Submit your manuscript to a SpringerOpen ${ }^{\circ}$ journal and benefit from:}

- Convenient online submission

- Rigorous peer review

- Open access: articles freely available online

- High visibility within the field

- Retaining the copyright to your article

Submit your next manuscript at $\boldsymbol{\nabla}$ springeropen.com 